\title{
Karakter Masyarakat Indonesia Berdasarkan Peribahasa
}

\section{Siriporn Maneechukate}

Faculty of Liberal Arts, Maejo University, Thailand siripornm259@yahoo.com

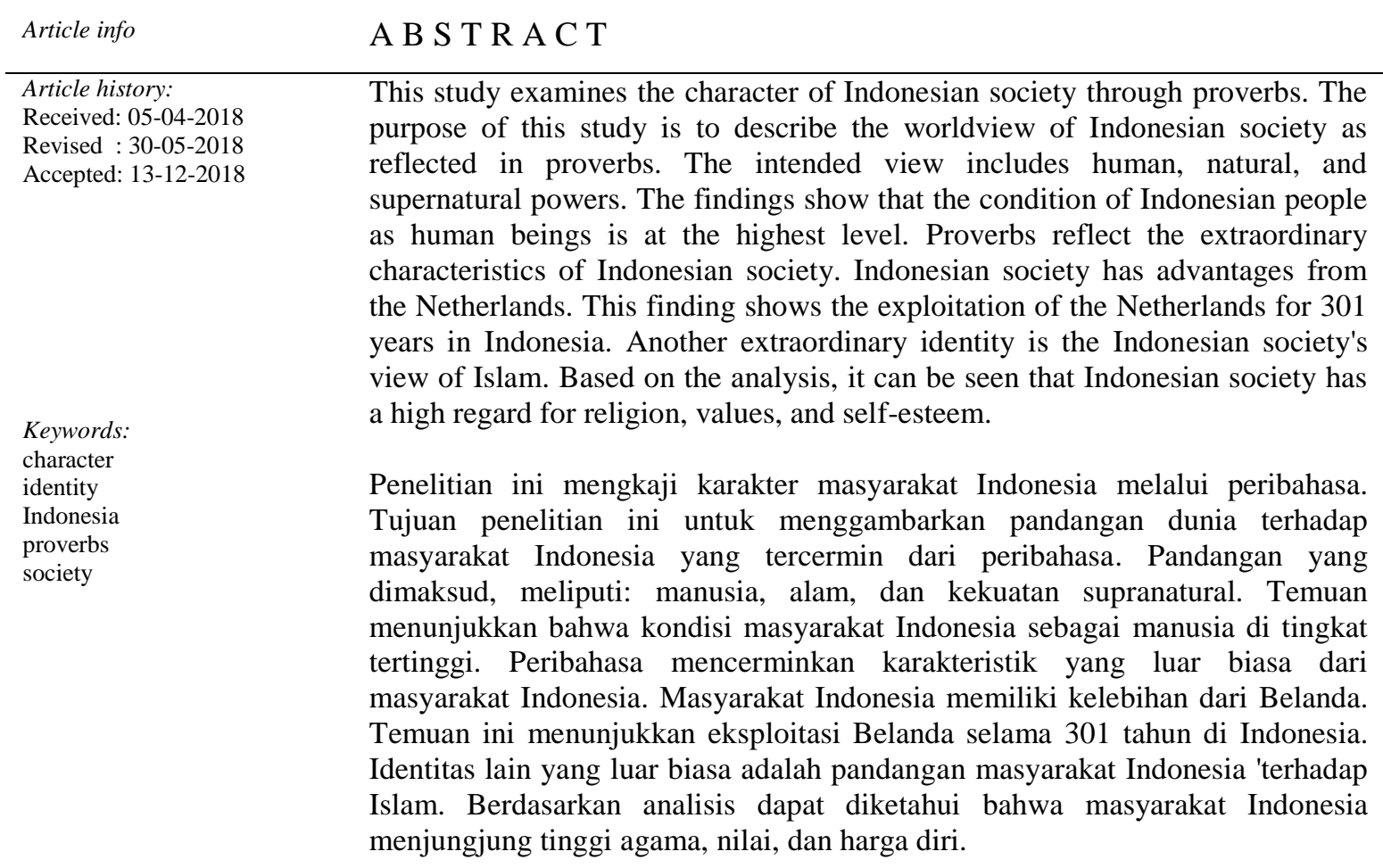

Copyright @ 2018 Institut Agama Islam Negeri Syekh Nurjati Cirebon. All rights reserved.

\section{PENDAHULUAN}

Penelitian ini mengkaji pandangan terhadap orang Indonesia berdasarkan 723 peribahasa. Tujuan penelitian ini adalah untuk mempelajari pandangan dunia dan cara hidup orang Indonesia yang tercermin dari peribahasa. Melalui peribahasa dapat dipelajari cara pandang orang Indonesia terhadap manusia, alam, dan kekuatan supranatural. Keberadaan peribahasa tidak dapat dilepaskan dari konteks kehidupan manusia itu sendiri (Sumanti, 2015). Salah satu cara untuk memahami budaya suku atau etnik adalah dengan mempelajari dan memahami ungkapan-ungkapan atau peribahasa-peribahasa yang terdapat dalam bahasa. Peribahasa mengandung nilai-nilai sosial, budaya, ekonomi, religiositas, pandangan hidup, kepemimpinan, bahkan nilai-nilai politik. Peribahasa, antara lain, berfungsi sebagai nasihat, kritik, prinsip hidup, atau aturan tingkah laku. Dalam peribahasa juga terkandung nilai-nilai kearifan, misalnya: rendah hati, sopan santun, tidak pamrih, tidak berputus asa, menjaga kehormatan, dan nilai gotong royong. Peribahasa merupakan 
unsur yang lazim terdapat dalam bahasa dan menjadi bagian tak terpisahkan dalam hidup dan berkembangnya bahasa (Untoro, 2009).

\section{METODE}

Penelitian deskriptif kualitatif ini mengambil sampel peribahasa yang ada di Indonesia. Data penelitian berupa peribahasa yang ditulis oleh Ramadhan (2002). Berbagai peribahasa yang ada dipilih secara acak lalu dianalisis. Adapun keabsahan data menggunakan triangulasi. Empat macam triangulasi yang bisa digunakan, meliputi: 1) triangulasi data (data triangulation), 2) triangulasi peneliti (investigator triangulation), 3) triangulasi metode (methodological triangulation), dan 4) triangulasi teoretis (theoretical triangulation). Analisis data meliputi tiga hal, yakni 1) reduksi data, 2) sajian data, dan 3) penarikan simpulan. Aktivitas analisis dilakukan dalam bentuk interaktif dengan proses pengumpulan data sebagai suatu siklus, yakni klasifikasi data, kodifikasi dan analisis data, penghayatan dan pengayaan teori, serta interpretasi data (Denik, 2015).

\section{HASIL DAN PEMBAHASAN}

\section{Pandangan terhadap Gender}

Pandangan orang Indonesia terhadap kaum perempuan memiliki nilai tersendiri. Para perempuan di Indonesia diharapkan bahwa saat menjelang dewasa, sudah pantas untuk berumah tangga, bagaikan "beban sudah di pintu" (Ramadhan, 2002). Jika perempuan lincah dan suka sekali ke luar rumah bagaikan "cacing gila" (Ramadhan, 2002). Menurut orang Indonesia, perempuan genit adalah perempuan yang kurang baik perangainya, bagaikan "perempuan jungkat" (Ramadhan, 2002). Selain itu, selalu mencampuri urusan orang lain dianggap sebagai salah satu ciri khas seorang perempuan, seperti yang terlihat dalam peribahasa "serupa paham perempuan" (Ramadhan, 2002).

\section{Pandangan terhadap Usia}

Menurut orang Indonesia, anak ketika masih kecil menyenangkan hati. Namun setelah besar menyusahkan hati seperti peribahasa "Kecil-kecil anak kalau sudah besar menjadi onak" (Ramadhan, 2002). Memang masa kanak-kanak diumpamakan masa yang suci sebagai kain putih. Jika dimulai secara baik akan menjadi baik, jika dimulai secara buruk akan menjadi buruk. Suatu kebiasaan buruk semenjak kecil sukar dihilangkan 
setelah dewasa seperti peribahasa "Kecil teranja-anja besar terbawa-bawa "(Ramadhan, 2002). Orang Indonesia memandang masa muda menjadi masa percaya diri dan menjadi perihal orang muda yang sombong dan tidak mau berunding dengan keluarga, karena menganggap dirinya pandai seperti peribahasa "Sudah tua dari kakak, sudah cerdik dari mamak" (Ramadhan, 2002). Orang Indonesia memandang masa tua menjadi masa yang banyak pengalaman, makin tua makin ahli seperti peribahasa peribahasa "Tua-tua kelapa, makin tua makin berminyak"(Ramadhan, 2002).

\section{Pandangan terhadap Hati}

Orang Indonesia berpandangan mengenai hati bahwa kalau hati senang, segala pekerjaan yang berat tak akan terasa. Hal ini seperti peribahasa "Biar badan penat, asalkan hati senang" (Ramadhan, 2002). Namun demikian, hatinya tidak terduga. Sesuatu yang tersembunyi di dalam hati seseorang tidak dapat diketahui, seperti dalam peribahasa "Dalam laut boleh diajuk, dalam hati siapa tahu" (Ramadhan, 2002). Hal ini sesuai dengan perilaku masyarakat Indonesia, khususnya masyarakat Jawa. Masyarakat Jawa sangat menjunjung sopan santun sehingga meskipun seseorang tidak suka dengan orang lain, senyum dan keramahan tetap diberikan.

\section{Pandangan terhadap Emosi dan Perasaan}

Orang Indonesia memandangkan terhadap perasaan cinta bahwa cinta kasih orang tua terhadap anak abadi, tetapi cinta kasih terhadap orang tua hanya sementara, seperti yang terlihat dalam peribahasa "Kasih ibu sepanjang jalan, kasih anak sepanjang penggalan "(Ramadhan, 2002).

\section{Pandangan terhadap Pikiran}

Orang Indonesia memproyeksikan pandangan dunia terhadap pikiran bahwa memberi nasihat kepada orang yang jahat atau bodoh terlalu sukar masuknya, seperti yang terlihat dalam peribahasa "Bagai air titik ke batu" (Ramadhan, 2002). Adapun orang pintar serta berpengalaman itu tempat bertanya, seperti yang terlihat dalam peribahasa "Adat teluk timbunan kapal, adat gunung tepatan kabut" (Ramadhan, 2002). Selain itu, orang Indonesia berpandangan negatif terhadap orang Belanda yang menyakiti orang Indonesia selama lebih dari 300 tahun, seperti yang terlihat dalam peribahasa "Bagai Belanda minta tanah" (Ramadhan, 2002). Peribahasa ini berarti orang yang sangat serakah, sudah diberi sedikit menginginkan yang lebih banyak. 


\section{Pandangan terhadap Kehormatan}

Orang Indonesia berpandangan lebih baik mati daripada hidup menanggung malu, seperti yang terlihat dalam peribahasa "Daripada hidup bercermin bangkai lebih baik mati berkalang tanah" (Ramadhan, 2002). Muhammad Rizieq Shihab yang mendeklarasikan berdirinya Front Pembela Islam mengatakan "Hiduplah secara mulia atau lebih baik mati secara syahid" (Taweesak 2012). Selain itu, pandangan dunia orang Indonesia juga menunjukkan sebaik-baiknya negeri orang, masih baik negeri sendiri meskipun kurang enak hidupnya, seperti yang terlihat dalam peribahasa "Hujan emas di negeri orang, hujan batu di negeri sendiri, baik juga di negeri sendiri" (Ramadhan, 2002).

\section{Pandangan terhadap Pemimpin}

Seorang pemimpin harus sabar dan banyak pertimbangan serta arif dan bijaksana, seperti yang terlihat dalam peribahasa "Adat penghulu berpandang luas beralam lapang" (Ramadhan, 2002). Jika dalam satu pekerjaan bila ada dua pemimpin pasti pekerjaan itu tidak akan beres, seperti yang terlihat dalam peribahasa "Biduk satu nakhoda dua" (Ramadhan, 2002). Akan tetapi, bila pemimpin telah kalah, maka pengikutnya pun akan kalah juga, seperti yang terlihat dalam peribahasa "Kalau pandai mencencang akar, mati lalu ke puncaknya" (Ramadhan, 2002).

\section{Pandangan terhadap Pengikut}

Sebagai pengikut, perilakunya akan mengikuti perilaku pemimpinnya. Setiap orang akan menurut kepada pembesar atau pemimpinnya, seperti yang terlihat dalam peribahasa "Bondong air bondong ikannya (dedak)" (Ramadhan, 2002).

\section{Pandangan terhadap Orang Tua}

Orang tua tidak akan tega mencelakakan anak sendiri, walaupun dosa besar sekalipun, seperti yang terlihat dalam peribahasa "Harimau tak akan makan anaknya" (Ramadhan, 2002). Namun, orang tua harus memarahi bila perbuatannya salah, seperti yang terlihat dalam peribahasa "Kasihan anak tangan-tangankan, kasihan bini tinggaltinggalkan" (Ramadhan, 2002).

\section{Pandangan terhadap Anak-Anak}

Segala nasihat orang tua harus ditaati anak-anak dengan sungguh-sungguh, seperti yang terlihat dalam peribahasa "Di mana bumi dipijak, di sana langit dijunjung" (Ramadhan, 2002). Selain itu, biasanya setiap anak senantiasa akan mencontoh atau 
menurun tabiat orang tuanya, seperti yang terlihat dalam peribahasa "Ke manakah tumpah hujan dari bubungan, kalau tidak ke cucuran atap". (Ramadhan, 2002).

\section{Pandangan terhadap Keluarga}

Menurut orang Indonesia, dalam keluarga itu tidak akan bercerai berai, walaupun terjadi perselisihan, seperti yang terlihat dalam peribahasa "Air dicencang tiada putus" (Ramadhan, 2002). Masyarakat Indonesia mengutamakan kebersamaan dan gotong royong. Hal ini dapat dilihat dari aktifitas yang ada di keluarga. Semua anggota keluarga akan saling membantu dan menolong satu sama lain.

\section{Pandangan terhadap Saudara}

Hubungan persaudaraan tidak mungkin diputuskan hubungannya meskipun berselisih pasti akan berakhir dengan damai, seperti yang terlihat dalam peribahasa "Cencang air tidak putus" (Ramadhan, 2002). Hal ini terutama pada keluarga yang sedarah. Artinya, keluarga yang berasal dari keturunan yang sama. Keluarga seperti ini akan tetap saling membantu walaupun terdapat perselisihan.

\section{Pandangan terhadap Kehidupan Suami Istri}

Orang Indonesia berpandangan terhadap kehidupan suami istri sebagai berikut. Sepasang suami-istri harus sesuai baik dari segi status keuangan dan ciri-ciri fisik, seperti dalam peribahasa "Bagai dulang dengan tudung saji" (Ramadhan, 2002). Suami istri harus hidup rukun sampai tua, seperti dalam peribahasa "Tangguk lerek dengan bingkainya" (Departemen Pendidikan Nasional, 2012) dan dalam hidupnya harus hanya beristri atau bersuami seorang, seperti dalam peribahasa "Lapuk oleh kain sehelai" (Departemen Pendidikan Nasional, 2012). Antara suami dan istri, sanak saudara terkadang terjadi perselisihan, seperti dalam peribahasa "Gigi dengan lidah ada kalanya tergigit pula" (Ramadhan, 2002).

\section{Pandangan terhadap Guru}

Guru harus memberi contoh yang baik, supaya muridnya meniru. Jika perilaku guru baik, produk muridnya juga baik. Jika perilaku guru buruk, produk murid akan jauh lebih buruk. Hal ini tercermin dalam peribahasa "Guru kencing berdiri, murid kencing berlari" (Ramadhan, 2002). Umumnya masyarakat Indonesia beranggapan bahwa guru adalah sosok yang hebat. Hebat yang dimaksud adalah serba tahu dan serba bisa. Oleh karena itu, 
guru hendaknya dapat menjadi contoh yang baik. Apa pun yang dilakukan guru akan diikuti atau diturut oleh murid.

\section{Pandangan terhadap Siswa}

Sebagai siswa, menuntut ilmu sebaiknya kepada orang yang berilmu pengetahuan dan kaya akan pengalaman, seperti dalam peribahasa "Belajar ke yang pintar, berguru ke yang pandai" (Ramadhan, 2002). Oleh karena itu, sebagai seorang murid harus memiliki niat yang benar dan motivasi yang tinggi untuk belajar. Murid atau siswa hendaknya mematuhi dan mengikuti segala hal yang diminta oleh guru atau pendidik.

\section{Pandangan terhadap Persahabatan}

Menurut orang Indonesia, dalam mencari kawan atau teman kita haruslah pandaipandai memilih, seperti dalam peribahasa "Berkawan dengan orang alim menjadi alim, berkawan dengan pencuri menjadi pencuri" (Ramadhan, 2002). Selain itu, setiap manusia akan mencari teman yang setingkat, sederajat, dan sekedudukan dengannya agar mudah bergaul, seperti dalam peribahasa "Antah berkumpul sama antah, beras berkumpul sama beras" (Ramadhan, 2002). Bagaimana pun, lebih mudah mendapatkan sahabat di waktu senang daripada di waktu susah, seperti dalam peribahasa "Kawan gelak banyak, kawan menangis jarang bersua" (Ramadhan, 2002).

\section{Pandangan terhadap Sosial dan Adat Istiadat}

Segala perbuatan hendaknya senantiasa mengingat akan adat dan hukum, dan tidak saling bertentangan, seperti yang terlihat dalam peribahasa "Adat bersendi syarak, syarak bersendi adat" (Ramadhan, 2002). Selain itu, orang Indonesia memiliki semboyan "Bhinneka Tunggal Ika", walaupun berbeda-beda, tetapi tetap satu. Hal inilah yang mnejadikan Indonesia damai dan sejahtera. Masyarakat Indonesia sudah terbiasa dengan berbagai perbedaan, baik budya, suku, ras, maupun agama.

\section{Pandangan terhadap Penjajah Belanda}

"Bagai Belanda minta tanah" (Ramadhan, 2002). Peribahasa ini berarti orang yang sangat serakah, sudah diberi sedikit menginginkan yang lebih banyak. Peribahasa ini ada latar belakang dari dongengnya. Seorang Belanda minta izin hendak memakai tanah, hanya seluas kulit sapi, akan tempat mendirikan sebuah kantor dan gudang. Setelah mendapat izin, maka diukurnya tanah itu: panjang dan lebarnya sama dengan panjang tali yang diperbuatnya daripada kulit sapi itu. (Pamuntjak, 2004). 
"Dahulu permata intan sekarang batu Belanda" (Ramadhan, 2002: 59) berarti dahulu dihormati sekarang tidak lagi dipandang. "Tidak mati oleh Belanda" (Ramadhan, 2002) berarti seorang yang telah kaya seakan-akan tidak akan jatuh miskin, sekalipun ia rugi berniaga misalnya. Peribahasa ini asalnya dari main kartu, main dua puluh satu. Jumlah mata kartu ada di tangan tiada lebih dari sebelas, jadi kalau tercabut Belanda (mata sepuluh) lagi, kartu itu tak kan mati (tiada lebih daripada dua puluh satu) (Pamuntjak, 2004).

\section{Pandangan terhadap Orang Cina}

Menurut orang Indonesia, orang Cina mempunyai percakapan yang sangat ramai atau hiruk-pikuk bunyinya, seperti dalam peribahasa "Bagaikan Cina karam" (Ramadhan, 2002).

\section{Pandangan terkait Cara Hidup}

Orang Indonesia berpandangan dunia akan cara hidup hemat. Hal ini seperti peribahasa berikut. "Ketika ada jangan dimakan, bila habis baru dimakan" (Ramadhan, 2002) sebaiknya memiliki simpanan yang dapat digunakan bila tidak ada penghasilan masih mempunyai simpanan. Hal ini menunjukkan bahwa masyarakat Indonesia telah mengenal budaya menabung. Selain itu, masyarakat Indonesia juga terbiasa hidup sederhana. Hal ini tampak pada peribahasa "Asal ada, kecil pun ada" (Ramadhan, 2002) berarti walau hanya sedikit, tetapi cukup juga.

Pandangan hidup masyarakat Indonesia juga mengajarkan untuk bersabar, berhatihati, serta bertanggung jawab. Hal ini dapat dilihat pada peribahasa berikut. "Adat muda menanggung rindu, adat tua memagar ragam" (Ramadhan, 2002) berarti yang muda maupun yang tua harus bersabar dalam menghadapi kesukaran. Artinya, ketika datang suatu musibah atau masalah, seseorang harus berusaha menyelesaikan masalah tersebut dan tetap bersabar. "Sedia payung sebelum hujan" (Ramadhan, 2002) berarti berjaga-jaga (berhati-hatilah) dahulu sebelum terjadi sesuatu. Artinya, sebelum masalah datang, seseorang hendaknya mengantisipasi. "Menjadi alas bubur" (Ramadhan, 2002) berarti diri sendirilah yang mesti menanggung segala beban atau risikonya. Bubur biasanya disajikan dalam keadaan panas. Bubur dapat dimaknai sebagai sebuah masalah. Oleh karena itu, seseorang harus dapat menyelesaikan masalahnya sendiri. Jangan sekali pun menyalahkan orang lain atau bergantung pada orang lain. 
Pandangan hidup lainnya, meliputi: berusaha, kesalehan, dan menepati janji. Hal ini seperti peribahasa "Alang-alang mandi biar basah" (Ramadhan, 2002) berarti mengerjakan sesuatu harus dengan tuntas. "Utang emas dapat dibayar, utang budi dibawa mati "(Ramadhan, 2002) berarti budi baik seseorang tetap akan diingat dan takkan terlupakan selamanya. Orang harus memegang janji dengan erat dan mengikat simpul cepat. Bagaikan peribahasa "Menggenggam erat membuhul mati" (Ramadhan, 2002).

Peribahasa lain juga menunjukkan pandangan hidup masyarakat Indonesia, seperti tolong-menolong, melakukan kebaikan, menghindari perbuatan buruk, tidak menilai orang lain, rendah hati, serta tidak sombong. Dalam kehidupan, seseorang harus bergaul dan bermasyarakat, tolong-menolong dan jenguk-menjenguk kala susah dan senang, seperti dalam peribahasa "Adat hidup tolong-menolong, adat mati jenguk-menjenguk "(Ramadhan, 2002). Hidup tiada artinya, jika tidak dipergunakan untuk berbuat kebajikan, seperti dalam peribahasa "Biar hidup seribu tahun, tiada sembahyang apa gunanya" (Ramadhan, 2002). Memasuki penghidupan baru, dengan meninggalkan penghidupan lama yang buruk atau jahat, bagaikan peribahasa "Buangkan air yang keruh, mengambil air yang jernih " (Ramadhan, 2002). Jangan mengukur derajat orang lain dengan diri sendiri, bagaikan peribahasa "Jangan mengukur baju orang di badan sendiri" (Ramadhan, 2002). Hendaknya manusia selalu bersikap merendahkan diri terhadap siapa pun, bagaikan peribahasa "Duduk di bawah-bawah, mandi di hilir-hilir" (Ramadhan, 2002). Jangan membandingkan awak dengan orang berkuasa dan kaya-raya, seperti dalam peribahasa "Jangan melihat ke atas" (Ramadhan, 2002).

\section{Pandangan terkait Cara Hidup yang Tidak Diinginkan}

Peribahasa di Indonesia menunjukkan bahwa masyarakat tidak: suka hidup boros, pemalu, kikir, malas, dan ingkar janji. Bagaikan peribahasa "Kalau boros lekas kerugian" (Ramadhan, 2002). Bagaikan peribahasa "Tebal kulit muka" (Ramadhan, 2002). Orang yang terlalu kikir, tak pernah memberikan bantuan/sumbangan apa pun, bagaikan peribahasa "Air digenggam tiada tiris" (Ramadhan, 2002). Bagaikan peribahasa "Bagai birah tak berakar" (Ramadhan, 2002). Bagaikan peribahasa "Ke atas tak berpucuk, ke bawah tak berakar, di tengah-tengah digirik kumpang" (Ramadhan 2002). 


\section{Pandangan Dunia terhadap Alam}

Peribahasa di Indonesia juga mencerminkan pandangan terhadap alam sebagai berikut. Artinya, masyarakat Indonesia sangat menjaga kelestarian dan keseimbangan hidup dengan alam sekitar.

\section{Pandangan terhadap Tanaman}

"Kecil-kecil cabai rawit" (Ramadhan, 2002) berarti meskipun kecil, tetapi orangnya sangat cerdik dan pemberani. Peribahasa ini juga mengajarkan agar jangan melihat sesuatu dari hal yang kecil. Bentuk yang kecil justru memiliki kekuatan yang luar biasa. Hal ini sama seperti cabai. Walaupun capai berbentuk kecil, tetapi kepedasan rasanya mengalahkan cabai yang besar. "Tambah air, tambah sagu” (Ramadhan 2002) berarti bila bertambah anak, bertambah pula rezekinya. Sagu merupakan makanan pokok sebagian besar masyarakat Indonesia yang tinggal di wilayah Timur. Air dimaknai sebagai sumber kehidupan. Telah diketahui bersama bahwa tumbuhan akan hidup subur jika mendapat air yang cukup. Demikian pun dengan sagu.

\section{Pandangan terhadap Hewan}

"Tak ada harimau memakan anaknya" (Ramadhan, 2002) berarti tiada orang tua yang ingin mencelakakan anak kandungnya. Peribahasan lain juga terdapat pada "Adakah buaya menolak bangkai" (Ramadhan, 2002) berarti orang yang bertabiat jahat itu, bila ada kesempatan tentu akan berbuat jahat pula. Hal ini juga muncul pada "Bagaikan anjing makan muntahnya" (Ramadhan, 2002) berarti orang tamak yang tidak dapat membedakan yang baik maupun buruk asalkan mendapat harta. Pandangan terhadap hewan juga terdapat pada "Bagaikan ayam, kais pagi makan pagi, kais petang makan petang" (Ramadhan, 2002) berarti orang miskin, bila tiada mau bekerja, tiada mendapatkan makan atau rezeki. Demikian juga dengan peribahasa "Baik jadi ayam betina supaya selamat" (Ramadhan, 2002) berarti Tidak perlu menunjukkan keberanian dan keombongan diri untuk menghindarkan diri dari malapetaka. Sama halnya dengan peribahasa "Bagai babi merasai gulai” (Ramadhan, 2002) berarti tidak layak orang hina mengharapkan dengan orang bangsawan. Peribahasa yang sudah lama dikenal, yakni "Ada air, ada ikan” (Ramadhan, 2002) berarti di manapun kita berada, niscaya ada rezeki. 


\section{Pandangan terhadap Lingkungan}

Beberapa peribahasa menunjukkan pandangan masyarakat Indonesia terhadap lingkungan, seperti "Hancur badan di kandung tanah, budi baik dikenang jua" (Ramadhan, 2002) berarti budi bahasa yang baik itu akan dikenang dan takkan pernah dilupakan. Demikian juga dengan "Air beriak tanda tak dalam" (Ramadhan, 2002) berarti orang yang banyak bicaranya serta sombong biasanya tidak banyak ilmu. Peribahasa yang juga menunjukkan pandangan terhadap lingkungan nampak pada "Kemana angin deras, di situ condongnya" (Ramadhan, 2002) berarti orang yang tidak mempunyai pendirian, mengikut saja pada pendapat atau perkataan orang lain. Sama halnya dengan peribahasa "Kalau tak ada api, masakan ada asap" (Ramadhan, 2002) berarti bila tidak bersalah, tidak mungkin dituduh. Demikian juga peribahasa "Bintang terang" (Ramadhan, 2002) berarti hidup seseorang dalam keadaan keperuntungan.

\section{Pandangan terhadap Agama}

Mayoritas orang Indonesia adalah muslim yang taat beragama, sebagaimana tercermin dalam peribahasa "Tidur orang alim lebih baik daripada puasa orang jahil" (Ramadhan, 2002) berarti tidur orang alim itu senantiasa dengan kebaikan jua, tetapi puasa orang jahil itu dengan kejahatan. Orang Indonesia berpandangan bahwa hidup tiada artinya, jika tidak dipergunakan kebajikan, seperti yang terlihat dalam peribahasa "Biar hidup seribu tahun, tiada sembahyang apa gunanya" (Ramadhan, 2002).

\section{Pandangan terhadap Kepercayaan Tuhan}

Orang Indonesia memandang bahwa tidak seorang pun dapat menentukan kematian, karena takdir maut sudah ditentukan oleh Tuhan, seperti yang terlihat dalam peribahasa "Sebelum ajal berpantang mati" (Ramadhan, 2002). Pada hakikatnya, manusia adalah hamba yang telah ditetapkan empat hal, yakni: jodoh, rejeki, hidup, dan mati. Berdasarkan hal tersebut dapat diketahui bahwa manusia tidak dapat menentukan hidup dan mati. Hanya Tuhan sebagai pencipta manusialah yang dapat menentukan hidup dan mati seseorang.

\section{Pandangan terhadap Hukum Karma, Kebaikan, dan Keburukan}

Masyarakat Indonesia memandang bahwa perbuatan baik akan mendapat ganjaran kebaikan sedangkan perbuatan buruk akan mendapat ganjaran keburukan, seperti yang 
Indonesian Language Education and Literature

e-ISSN: 2502-2261

http://www.syekhnurjati.ac.id/jurnal/index.php/jeill/

Vol. 4, No. 1, Desember 2018, $91-102$

terlihat dalam peribahasa "Adat dunia balas-membalas, syariat palu-memalu." (Ramadhan, 2002).

\section{SIMPULAN}

Penelitian peribahasa Indonesia adalah salah satu cara untuk mengakses bahasa, budaya, tradisi, agama dan pandangan dunia orang Indonesia karena peribahasa menjadi hasil dari hal-hal tersebut. Untoro (2009) mengatakan bahwa peribahasa mengandung nilai-nilai sosial, budaya, ekonomi, religiositas, pandangan hidup, kepemimpinan, bahkan nilai-nilai politik. Peribahasa, antara lain, berfungsi sebagai nasihat, kritik, prinsip hidup, atau aturan tingkah laku. Dalam peribahasa juga terkandung nilai-nilai kearifan, misalnya: rendah hati, sopan santun, tidak pamrih, tidak berputus asa, menjaga kehormatan, dan nilai gotong royong. Hasil penelitian pandangan dunia orang Indonesia dari 723 peribahasa bisa dibentukkan 3 pandangan dunia: pandangan orang Indonesia terhadap manusia, alam, dan kekuatan supranatural. Hasil penelitian ini menunjukkan dua identitas terkemuka di Indonesia: 1) peribahasa mencerminkan pandangan negatif orang Indonesia terhadap Belanda pada zaman dahulu dan 2) pandangan terhadap agama Islam tetap kuat dan tidak berubah.

\section{DAFTAR PUSTAKA}

กิ่งแก้ว แห้วสุโน. (2552). อุปลักษณ์ในภาษาญ้อบ้านดงเย็น อำเภอเมือง จังหวัดมุกดาหาร. (วิทยานิพนธ์ปริญญามหาบัณฑิต). มหาวิทยาลัยมหาสารคาม.

\section{กีรติกานต์ บุญฤทธิ์ และคณะ. (2551). โลกทัศน์ในรวมบทกวีนิพนธ์ ม้าก้านกล้วยของไพวรินทร์ ขาวงาม.}

วารสารวิชาการคณะมนุษยศาสตร์และสังคมศาสตร์. 4 (2), 7-34.

ทวีศักดิ์ เผือกสม. (2555). ประวัติศาสตร์อินโดนีเซีย: รัฐจารีตบนหมู่เกาะ ความเป็นสมัยใหม่แบบอาณานิคม และสาธารณรัฐแห่งความหลากหลาย. กรุงเทพฯ: เมืองโบราณ.

ราชบัณฑิตยสถาน. (2556). พจนานุกรม ฉบับราชบัณฑิตยสถาน พ.ศ. 2554 เฉลิมพระเกียรติพระบาทสมเด็จพระเจ้าอยู่หัวเนื่องในโอกาสพระราชพิธีมหามงคลเ ฉลิมพระชนมพรรษา 7 รอบ 5 ธันวาคม 2554 . กรุงเทพฯ : ราชบัณฑิตยสถาน.

วิทย์ บัณฑิตกุล. (2555). สาธารณรัฐอินโดนีเซีย. กรุงเทพฯ : สถาพรบุ๊คส์.

สุภาพร

คงศิริรัตน์.

การศึกษาพระโลกทัศน์ของพระบาทสมเด็จพระจุลจอมเกล้าเจ้าอยู่หัวที่ปรากฏในพร 
Indonesian Language Education and Literature

e-ISSN: 2502-2261

http://www.syekhnurjati.ac.id/jurnal/index.php/jeill/

Vol. 4, No. 1, Desember 2018, $91-102$

\section{ะราชหัตถเลขา. (วิทยานิพนธ์ปริญญาดุษฎีบัณฑิต). พิษณุโลก} มหาวิทยาลัยนเรศวร.

อุบล เทศทอง. (2548). ภาษิตเขมร: วิถีชีวิตและโลกทัศน์ของชาวเขมร. บัณฑิตวิทยาลัย มหาวิทยาลัยศิลปากร.

Arimi, S. (2005). Contested Wisdom in Indonesian and Japanese Proverbs: A LinguisticCultural Mapping. 都市文化研究 Studies in Urban Cultures, 6, 76-101.

Denik, W. (2015). Analisis Wacana Naskah Drama “Esok, di Neraka.” Journal Indonesian Language Education and Literature, 1(1), 75-89. DOI: http://dx.doi.org/10.24235/ileal.v1i1.73.

Departemen Pendidikan Nasional. (2012). Kamus Besar Bahasa Indonesia Pusat Bahasa Edisi Keempat. Jakarta: PT Gramedia.

Dharma, A. (2011). Pembinaan dan Pengembangan Bahasa Daerah. International Seminar "Language Maintenance and Shift", July 2, 2011 Diponegoro University.

Hidayat, P. M. S. (1994). Inti Sarikata Bahasa Indonesia. Surabaya: Apollo.

Jenkins, R. (1997). Rethinking Ethnicity. London: Sage Publications.

Kongres Internasional Masyarakat Linguistik Indonesia (KIMLI), November, 5-7 2009 Malang.

Pamuntjak, K. St. (2004). Peribahasa. Jakarta: Balai Pustaka.

Ramadhan, S. (2002). Kamus Lengkap Peribahasa Indonesia. Surabaya: Amelia.

Sumanti. (2015). Analisis Wacana Novel Supernova: Akar Karya Dee Lestari (Sebuah Tinjauan Referensi). Journal Indonesian Language Education and Literature, 1(1), 16-28. DOI: http://dx.doi.org/10.24235/ileal.v1i1.49.

Supriyadi, H. (2010). The Meanings of Sanskrit Loanwords in Standard Thai and Javanese from Socio-Cultural Perspectives. (Doctoral dissertation). Bangkok: Mahidol University.

Untoro, S. (2009). Peribahasa Bahasa-bahasa Daerah Sebagai Cermin Keanekaragaman Budaya di Indonesia.

Widyastuti, S. (2010). Peribahasa: Cermin Kepribadian Budaya Lokal dan Penerapannya di Masa Kini. Proceeding of National Seminar of Yogyakarta University of Technology. 